\title{
Zinc and vegetarian diets
}

\begin{abstract}
A lthough vegetarians have an overall lower risk of common chronic diseases than non-vegetarians, there are some nutrients, including zinc, that need special attention in those who follow a vegetarian diet. Since plant sources of zinc contain phytate and other inhibitors of zinc absorption, vegetarians and vegans may potentially be at risk of zinc deficiency. We present a review of the evidence about zinc in relation to vegetarians, including the bioavailability of zinc from plant sources. We also consider the body's adaptive homeostatic mechanisms and what these mean in terms of vegetarians' zinc status and dietary requirements.
\end{abstract}

\section{Zinc's important role}

Zinc is a trace mineral abundantly distributed throughout all body tissues and fluids, and second only to iron among trace elements in the body. It is essential for multiple aspects of metabolism, including catalytic, structural and regulatory functions, and also plays an important role in the immune system. ${ }^{1,2}$ Zinc is a catalyst for a large number of metabolic enzymes $(>50){ }^{2}$ It helps maintain structural integrity of some proteins and can play a role in the regulation of gene expression. ${ }^{3}$ Sixty per cent of total body zinc content is in skeletal muscle and $30 \%$ is in bone mass, with plasma zinc representing less than 1\%. High concentrations are found in the choroid of the eye and in prostatic fluids. ${ }^{1}$ In blood plasma, zinc is bound to and transported by albumin and transferrin. ${ }^{4}$

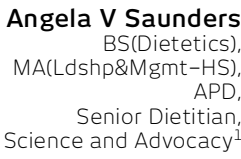

\section{Dietary sources of zinc}

Dietary zinc is available from plant and animal sources (Box 1). The recommended dietary intake (RDI) for vegetarians is $12 \mathrm{mg} /$ day for women and $21 \mathrm{mg} /$ day for men (Box 2). This is $150 \%$ of the RDI for the general Australian population, based on the lower bioavailablity of zinc from a vegetarian diet (see below). Lean red meat, wholegrain cereals and legumes provide the highest concentrations of zinc, generally in the range of 2.5$5.0 \mathrm{mg} / 100 \mathrm{~g}$ raw weight. ${ }^{1}$ As zinc is contained within the outer layer of grains, unrefined whole grains provide higher concentrations of zinc than refined grains (up to $5.0 \mathrm{mg} / 100 \mathrm{~g}$, compared with $1.0 \mathrm{mg} / 100 \mathrm{~g}$ ). ${ }^{7}$ Wholegrain breads and cereals, rolled oats, brown rice, nuts, seeds, legumes, tofu, soy products and fortified breakfast cereals are important dietary sources of zinc for everyone, not just vegetarians. Fruit and green leafy vegetables have much lower concentrations of zinc due to their high water content. $^{8}$

\section{Bioavailability of zinc - inhibitors and enhancers}

The main inhibitor of dietary zinc absorption is phytic acid found in legumes, unrefined cereals, seeds and nuts. ${ }^{9}$ Phytate forms an insoluble complex by chelating with zinc,

\section{Summary}

Well planned vegetarian diets can provide adequate amounts of zinc from plant sources.

- Vegetarians appear to adapt to lower zinc intakes by increased absorption and retention of zinc.

Good sources of zinc for vegetarians include whole grains, tofu, tempeh, legumes, nuts and seeds, fortified breakfast cereals and dairy products.

- The inhibitory effects of phytate on absorption of zinc can be minimised by modern food-processing methods such as soaking, heating, sprouting, fermenting and leavening.

Absorption of zinc can be improved by using yeastbased breads and sourdough breads, sprouts, and presoaked legumes.

- Studies show vegetarians have similar serum zinc concentrations to, and no greater risk of zinc deficiency than, non-vegetarians (despite differences in zinc intake).

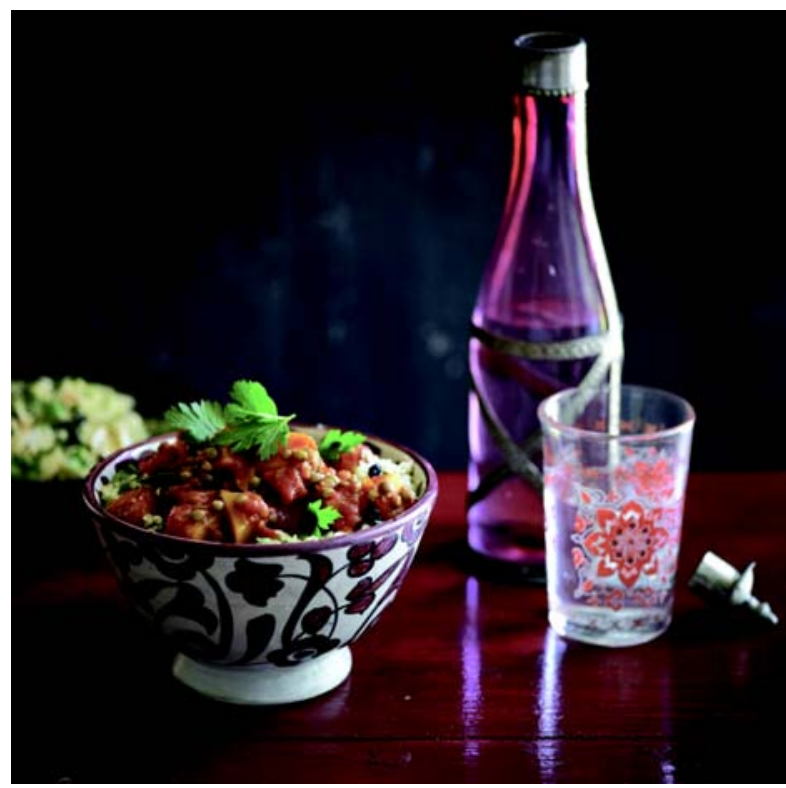

inhibiting absorption. ${ }^{10}$ The molar ratio of phytate to zinc in the diet has been used to predict zinc bioavailability, and ratios greater than 15 have been associated with suboptimal zinc status. ${ }^{11}$

The inhibitory effect can be overcome by foodprocessing techniques that use enzymes or thermal processing to hydrolyse phytic acid. ${ }^{11}$ Wheat grain contains the enzyme phytase that breaks down phytate during yeast fermentation, and the heat during baking destroys over $50 \%$ of the phytate in yeast-leavened wholemeal breads or sourdough breads. ${ }^{10}$ Soaking and sprouting beans, grains and seeds also reduces phytate. ${ }^{12}$ Modern processing methods such as leavening and fermentation often achieve 


\section{Examples of plant and animal sources of dietary zinc*}

\begin{tabular}{|c|c|c|c|}
\hline Plant-derived foods & Zinc per $100 \mathrm{~g}$ & $\begin{array}{l}\text { Animal-derived } \\
\text { foods }\end{array}$ & Zinc per $100 \mathrm{~g}$ \\
\hline Sun-dried tomatoes & $13.6 \mathrm{mg}$ & Oysters, raw & $47.9 \mathrm{mg}$ \\
\hline Zinc-fortified breakfast cereals & $1.9-7.8 \mathrm{mg}$ & $\begin{array}{l}\text { Oysters, smoked or } \\
\text { canned }\end{array}$ & $14.7 \mathrm{mg}$ \\
\hline Pumpkin seeds & $7.5 \mathrm{mg}$ & $\begin{array}{l}\text { Beef, fillet, lean, } \\
\text { grilled }\end{array}$ & $7.8 \mathrm{mg}$ \\
\hline Sunflower seeds & $5.8 \mathrm{mg}$ & Lamb chop, grilled & $5.4 \mathrm{mg}$ \\
\hline Sesame seeds/tahini & $5.5 \mathrm{mg}$ & Cheddar cheese & $3.6 \mathrm{mg}$ \\
\hline Pine nuts/cashews & $5.3-5.5 \mathrm{mg}$ & $\begin{array}{l}\text { Kangaroo fillet, } \\
\text { grilled }\end{array}$ & $3.1 \mathrm{mg}$ \\
\hline $\begin{array}{l}\text { Sausage, vegetarian, zinc } \\
\text { fortified }\end{array}$ & $4.4 \mathrm{mg}$ & Pork fillet & $2.4 \mathrm{mg}$ \\
\hline Flaxseed $^{\dagger}$ & $4.3 \mathrm{mg}$ & Crabmeat, canned & $2.2 \mathrm{mg}$ \\
\hline Almonds/pecans/brazil nuts & $3.7-4.1 \mathrm{mg}$ & Fetta cheese & $1.8 \mathrm{mg}$ \\
\hline $\begin{array}{l}\text { Lentils/soy beans/kidney } \\
\text { beans, dried }\end{array}$ & $3.0-4.0 \mathrm{mg}$ & King prawns & $1.6 \mathrm{mg}$ \\
\hline $\begin{array}{l}\text { Whole wheat biscuit breakfast } \\
\text { cereal }\end{array}$ & $2.0-2.7 \mathrm{mg}$ & Egg, whole & $1.2 \mathrm{mg}$ \\
\hline Bread roll, mixed grain, toasted & $2.0 \mathrm{mg}$ & Milk, whole & $0.4 \mathrm{mg}$ \\
\hline
\end{tabular}

a molar ratio of phytate to zinc of below 12, so bioavailability is less of an issue. ${ }^{13}$ Zinc absorption from some legume-based diets (eg, white beans and lupin protein) is comparable with animal-protein-based diets despite a higher phytate content in the legumes. ${ }^{1}$ Due to modern processing methods and the wide variety of plantderived foods rich in zinc, zinc deficiency is less likely to be a problem in Western vegetarian diets compared with plant-based diets in developing countries.

Taking iron supplements may also inhibit zinc absorption, although the presence of iron in a meal that also contains zinc does not reduce zinc absorption. ${ }^{14}$ In the past, calcium and dietary fibre were also thought to inhibit zinc absorption; however, several studies have shown no significant differences in zinc absorption when calcium was added to infant cows milk formula compared with the regular level of calcium. ${ }^{12}$ Similarly, although foods high in phytic acid also contain high amounts of dietary fibre, fibre itself does not interfere with zinc absorption. ${ }^{15}$ Some studies have shown that the total amount of zinc in a meal may have a greater effect on zinc absorption than the presence of phytate. For example, in a comparison of white and wholemeal bread, the much higher zinc content of wholemeal bread resulted in more zinc being absorbed overall, even though bioavailability was half that of the white bread. ${ }^{16}$

Sulphur-containing amino acids (cysteine and methionine, found in a range of seeds, nuts, grains and vegetables) and hydroxy acids (citric acid found in citrus fruits, lactic acid in sour milk, malic acid in apples, tartaric acid in grapes) bind to zinc and enhance its absorption. ${ }^{12}$ Organic acids that are present in foods or produced during fermentation can also enhance zinc absorption but probably do so to a lesser extent than for iron absorption. ${ }^{17}$ Higher levels of dietary protein enhance zinc absorption, as zinc binds to proteins. Different types of protein influence zinc absorption in different ways. Casein in milk has an inhibitory effect on zinc absorption, whereas soy protein does not. ${ }^{12}$ The greater availability of zinc from human milk compared with cows milk, which has a much higher casein content than human milk, is an example of how protein digestibility influences zinc absorption. ${ }^{18}$

\section{Zinc regulation, absorption and adaptation}

The body has homeostatic mechanisms that tightly regulate plasma zinc concentration in spite of diverse dietary zinc intakes and differences in bioavailability. ${ }^{18}$ These mechanisms maintain zinc sufficiency by reducing endogenous zinc losses and increasing the efficiency of zinc absorption. ${ }^{2,19}$ Metallothionein and zinc transporters sense zinc status and coordinate exogenous and endogenous absorption, secretion and distribution. ${ }^{7,20,21}$ If zinc balance is not maintained, zinc is mobilised from a small, vulnerable and rapidly exchangeable pool. ${ }^{2}$ Plasma zinc concentrations and zinc bound to metallothionein are part of the zinc pool. Considerable amounts of zinc come from endogenous sources such as pancreatic secretions. ${ }^{19}$ Gut and pancreatic metallothionein concentrations respond rapidly to changes in dietary zinc intake, helping to maintain zinc homeostasis. ${ }^{2}$ The efficiency of zinc absorption also increases during periods

2 Estimated average requirement (EAR)* and recommended dietary intake (RDI) ${ }^{\dagger}$ of zinc per day, by sex and age group ${ }^{3}$

\begin{tabular}{|c|c|c|c|c|c|c|c|c|c|c|c|c|}
\hline \multirow[b]{2}{*}{$\begin{array}{l}\text { Age } \\
\text { (years) }\end{array}$} & \multicolumn{3}{|c|}{ Male } & \multicolumn{3}{|c|}{ Female } & \multicolumn{3}{|c|}{ Pregnant women } & \multicolumn{3}{|c|}{ Lactating women } \\
\hline & EAR & $\begin{array}{c}\text { RDI, } \\
\text { general }\end{array}$ & $\begin{array}{c}\text { RDI, } \\
\text { vegetarian }\end{array}$ & EAR & $\begin{array}{c}\text { RDI, } \\
\text { general }\end{array}$ & $\begin{array}{c}\text { RDI, } \\
\text { vegetarian }\end{array}$ & EAR & $\begin{array}{c}\text { RDI, } \\
\text { general }\end{array}$ & $\begin{array}{c}\text { RDI, } \\
\text { vegetarian }\end{array}$ & EAR & $\begin{array}{c}\text { RDI, } \\
\text { general }\end{array}$ & $\begin{array}{c}\text { RDI, } \\
\text { vegetarian }\end{array}$ \\
\hline $1-3$ & $2.5 \mathrm{mg}$ & $3 \mathrm{mg}$ & $4.5 \mathrm{mg}$ & $2.5 \mathrm{mg}$ & $3 \mathrm{mg}$ & $4.5 \mathrm{mg}$ & - & - & - & - & - & - \\
\hline $4-8$ & 3 mg & $4 \mathrm{mg}$ & $6 \mathrm{mg}$ & $3 \mathrm{mg}$ & $4 \mathrm{mg}$ & $6 \mathrm{mg}$ & - & - & - & - & - & - \\
\hline $9-13$ & $5 \mathrm{mg}$ & $6 \mathrm{mg}$ & 9 mg & $5 \mathrm{mg}$ & $6 \mathrm{mg}$ & $9 \mathrm{mg}$ & - & - & - & - & - & - \\
\hline $14-18$ & $11 \mathrm{mg}$ & $13 \mathrm{mg}$ & $19.5 \mathrm{mg}$ & $6 \mathrm{mg}$ & $7 \mathrm{mg}$ & $10.5 \mathrm{mg}$ & $8.5 \mathrm{mg}$ & $10 \mathrm{mg}$ & 15 mg & 9 mg & $11 \mathrm{mg}$ & $16.5 \mathrm{mg}$ \\
\hline $19-30$ & $12 \mathrm{mg}$ & $14 \mathrm{mg}$ & 21 mg & $6.5 \mathrm{mg}$ & $8 \mathrm{mg}$ & 12 mg & $9.0 \mathrm{mg}$ & $11 \mathrm{mg}$ & $16.5 \mathrm{mg}$ & $10 \mathrm{mg}$ & $12 \mathrm{mg}$ & 18 mg \\
\hline $31-50$ & $12 \mathrm{mg}$ & $14 \mathrm{mg}$ & $21 \mathrm{mg}$ & $6.5 \mathrm{mg}$ & $8 \mathrm{mg}$ & $12 \mathrm{mg}$ & $9.0 \mathrm{mg}$ & $11 \mathrm{mg}$ & $16.5 \mathrm{mg}$ & 10 mg & $12 \mathrm{mg}$ & $18 \mathrm{mg}$ \\
\hline $51-70$ & $12 \mathrm{mg}$ & $14 \mathrm{mg}$ & $21 \mathrm{mg}$ & $6.5 \mathrm{mg}$ & $8 \mathrm{mg}$ & $12 \mathrm{mg}$ & - & - & - & - & - & - \\
\hline$>70$ & $12 \mathrm{mg}$ & $14 \mathrm{mg}$ & $21 \mathrm{mg}$ & $6.5 \mathrm{mg}$ & $8 \mathrm{mg}$ & $12 \mathrm{mg}$ & - & - & - & - & - & - \\
\hline
\end{tabular}

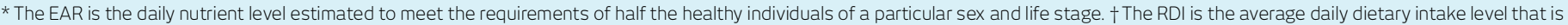

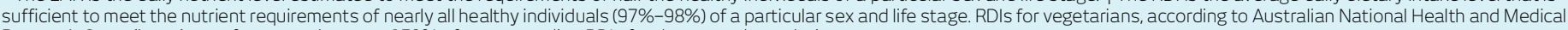
Research Council nutrient reference values, are $150 \%$ of corresponding RDIs for the general population. 


\section{Zinc recommendations for men}

\begin{tabular}{|c|c|c|c|c|}
\hline Level of bioavailability: type of diet & $\begin{array}{l}\text { Phytate: zinc } \\
\text { molar ratio }\end{array}$ & $\begin{array}{l}\text { Assumed } \\
\text { bioavailability }\end{array}$ & $\begin{array}{l}\text { WHO recommendation, } \\
\text { 19-65+ years }\end{array}$ & $\begin{array}{l}\text { Australian RDI,* 19-70+ years } \\
\text { for non-vegetarians }{ }^{3}\end{array}$ \\
\hline Low: entirely unrefined plant-based or vegan & $>15$ & $15 \%$ & 14 mg/day & \\
\hline $\begin{array}{l}\text { Moderate: omnivore, vegetarian (lacto-ovo) and } \\
\text { vegan (includes some refined cereals) }\end{array}$ & $5-15$ & $30 \%-35 \%$ & 7 mg/day & 14 mg/day \\
\hline $\begin{array}{l}\text { High: includes highly refined, low cereal fibre, large } \\
\text { amounts of meat }\end{array}$ & $<5$ & $50 \%-55 \%$ & $4.2 \mathrm{mg} /$ day & 14 mg/day \\
\hline
\end{tabular}

of high physiological demand (infancy, pregnancy and lactation). ${ }^{22}$ Plasma zinc concentrations are also influenced by infection, stress and fasting. ${ }^{2}$

Adaptation appears to occur in vegetarians, with zinc status likely to remain stable after an initial adjustment period. ${ }^{23,13}$ Reduced plasma and urinary zinc levels have been seen in the first 3 months of changing to a vegetarian diet, with no further reductions during 9 months of follow-up. ${ }^{24}$ This may be due to reduced endogenous zinc losses and increased efficiency of zinc absorption. ${ }^{2,3}$ Hence, vegetarians may have a lower zinc intake than non-vegetarians, but their zinc status appears to be protected after an initial adjustment period.

\section{Risk of zinc deficiency}

The prevalence of zinc deficiency is low in developed countries, whereas people in developing countries are at greater risk due to marginal zinc intake and dependence on unrefined grains, which are high in phytate. Diets in developing countries are also low in fruits and vegetables, foods that enhance zinc absorption and counteract the effect of phytate. Zinc deficiency can cause higher morbidity and mortality rates in children, and contributes to impaired growth and development. ${ }^{25}$

While zinc is involved in a wide variety of metabolic processes, mild clinical deficiency of zinc is difficult to detect or establish conclusively. The effects of mild or marginal zinc deficiency are reduced growth rate, reduced immunity, increased susceptibility to infection, impaired taste acuity and poor wound healing. ${ }^{1,26}$ The reasons for primary zinc deficiency include poor dietary bioavailability or high physiological demand during infancy, childhood, pregnancy and lactation. ${ }^{20}$ The effects of zinc deficiency can be particularly apparent during periods of rapid growth and development, such as infancy and adolescence. $^{27}$

In a national random survey of Australian adults, daily intakes of zinc were marginal, with $67 \%$ of men and $85 \%$ of women below the RDA (United States recommended dietary allowance) for zinc. ${ }^{28}$ Plasma or serum zinc levels are the most commonly used indices for evaluating zinc deficiency; however, plasma zinc concentrations are not considered a sensitive enough indicator to measure zinc status. ${ }^{11}$ Consequently, with the lack of sensitive clinical criteria, it is difficult to evaluate the long-term effects of marginal or low zinc intake in vegetarians. ${ }^{23}$

\section{Sources of zinc for lacto-ovo-vegetarians, per serve*}

\begin{tabular}{|c|c|}
\hline Food, serving size & $\begin{array}{c}\text { Zinc } \\
\text { per serve }\end{array}$ \\
\hline Brown rice, cooked, l cup & $1.9 \mathrm{mg}$ \\
\hline Tofu, firm, $100 \mathrm{~g}$ & $1.7 \mathrm{mg}$ \\
\hline Cashews, $30 \mathrm{~g}^{\dagger}$ & $1.7 \mathrm{mg}$ \\
\hline Cheese, 2 slices (42g) & $1.6-2.0 \mathrm{mg}$ \\
\hline Lentils, 3/4 cup & $1.6 \mathrm{mg}$ \\
\hline Pine nuts, $30 \mathrm{~g}^{\dagger}$ & $1.6 \mathrm{mg}$ \\
\hline Sundried tomatoes, 1 tablespoon ( $11.2 \mathrm{~g}$ ) & $1.5 \mathrm{mg}$ \\
\hline Green peas, frozen, $1 / 2$ cup & $1.5 \mathrm{mg}$ \\
\hline Soybeans, cooked/canned (1/2 cup) & $1.3 \mathrm{mg}$ \\
\hline Zinc-fortified breakfast cereals, 1/2 cup & $1.2 \mathrm{mg}$ \\
\hline Pumpkin seeds, 1 tablespoon $(15 \mathrm{~g})^{\dagger}$ & $1.2 \mathrm{mg}$ \\
\hline Pecans, $30 \mathrm{~g}^{\dagger}$ & $1.2 \mathrm{mg}$ \\
\hline Brazil nuts, $30 \mathrm{~g}^{\dagger}$ & $1.2 \mathrm{mg}$ \\
\hline Egg, whole & $1.2 \mathrm{mg}$ \\
\hline Almonds, $30 \mathrm{~g}^{\dagger}$ & $1.1 \mathrm{mg}$ \\
\hline Tempeh, $100 \mathrm{~g}$ & $1.1 \mathrm{mg}$ \\
\hline Cows milk, I cup $(250 \mathrm{~mL})$ & $0.9 \mathrm{mg}$ \\
\hline Sunflower seeds, 1 tablespoon $(15 \mathrm{~g})^{\dagger}$ & $0.9 \mathrm{mg}$ \\
\hline Mixed-grain bread, 2 slices & $0.7 \mathrm{mg}$ \\
\hline Wholemeal bread, 2 slices & $0.6 \mathrm{mg}$ \\
\hline Cocoa powder, 1 tablespoon (7g) & $0.6 \mathrm{mg}$ \\
\hline Peanut butter, 3 teaspoons ( $15 \mathrm{~g}$ ) & $0.5 \mathrm{mg}$ \\
\hline Tofu, silken, $100 \mathrm{~g}$ & $0.5 \mathrm{mg}$ \\
\hline
\end{tabular}

\section{Vegetarian zinc intake and status}

Zinc intake is a challenge for vegetarians and nonvegetarians alike. With good planning, vegetarians can consume enough zinc from legumes, wholegrain products and a frequent intake of nuts and seeds as well as fruits and vegetables that enhance absorption. Overall, zinc intakes from vegetarian diets are either similar to or lower than non-vegetarian diets. ${ }^{19}$ Because phytate or other dietary inhibitors in vegetarian diets typically decrease zinc absorption, there is normally a compensatory improved efficiency of absorption and excretion of zinc. ${ }^{2,18,19}$

A US study showed that the average daily zinc intake of long-term vegetarian women was $9.2 \mathrm{mg} .{ }^{29}$ In contrast, a more recent Australian study showed that the mean dietary zinc intake of lacto-ovo-vegetarian women was 


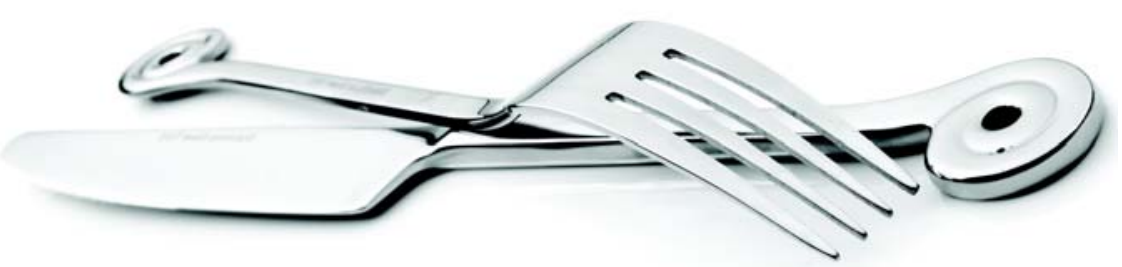

5 A sample vegetarian meal plan designed to meet the zinc requirements of a 70+-year-old lacto-ovovegetarian man, showing zinc content of the foods*

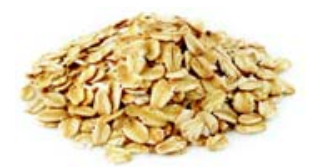

\begin{tabular}{lc} 
Meal & Zinc content \\
\hline Breakfast & \\
Rolled oats (1/2 cup dry oats) with & $1.0 \mathrm{mg}$ \\
l/2 cup low-fat fortified soy milk & $0.3 \mathrm{mg}$ \\
2 tablespoons wheatgerm & $0.9 \mathrm{mg}$ \\
10 g chopped walnuts & $0.3 \mathrm{mg}$ \\
30 g pumpkin seeds & $2.0 \mathrm{mg}$ \\
1 banana & $0.2 \mathrm{mg}$
\end{tabular}

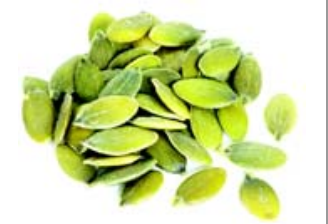

\begin{tabular}{ll}
\hline Snack & \\
l apple & $0.1 \mathrm{mg}$
\end{tabular}

\section{Hot chocolate}

1 cup low-fat fortified soy milk $\quad 0.5 \mathrm{mg}$

2 teaspoons cocoa powder $\quad 0.3 \mathrm{mg}$

1 teaspoon sugar $\quad 0.0 \mathrm{mg}$

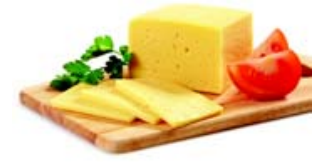

\begin{tabular}{ll}
\hline Lunch & \\
Mixed-grain-bread sandwich & \\
2 slices mixed-grain bread & $0.7 \mathrm{mg}$ \\
40 g cheese & $2.0 \mathrm{mg}$ \\
$1 / 2$ cup salad & $0.1 \mathrm{mg}$ \\
4 pieces sun-dried tomatoes & $1.6 \mathrm{mg}$ \\
Margarine & $0.0 \mathrm{mg}$ \\
$125 \mathrm{~mL}$ glass orange juice & $0.3 \mathrm{mg}$ \\
\hline Snack & \\
3 rye crispbread with & $0.6 \mathrm{mg}$ \\
I tablespoon tahini & $1.0 \mathrm{mg}$ \\
3 teaspoons honey & $0.3 \mathrm{mg}$
\end{tabular}

\begin{tabular}{|c|c|}
\hline Dinner & \\
\hline \multicolumn{2}{|l|}{ Lentil curry with vegetables and rice } \\
\hline $3 / 4$ cup lentils & $1.6 \mathrm{mg}$ \\
\hline $\begin{array}{l}\text { 1/2 cup pumpkin, } 1 / 2 \text { cup peas, } 1 / 4 \text { cup beans, } \\
1 / 4 \text { cup canned tomatoes }\end{array}$ & $2.4 \mathrm{mg}$ \\
\hline 40 g cashews & $2.2 \mathrm{mg}$ \\
\hline 2 teaspoons sesame seeds & $0.3 \mathrm{mg}$ \\
\hline 1 cup brown rice & $1.6 \mathrm{mg}$ \\
\hline \multicolumn{2}{|l|}{ Snack } \\
\hline $10 \mathrm{~g}$ walnuts & $0.3 \mathrm{mg}$ \\
\hline \multicolumn{2}{|l|}{ Hot chocolate } \\
\hline 1 cup low-fat fortified soy milk & $0.5 \mathrm{mg}$ \\
\hline 2 teaspoons cocoa powder & $0.3 \mathrm{mg}$ \\
\hline 1 teaspoon sugar & $0.0 \mathrm{mg}$ \\
\hline Total zinc & $21.4 \mathrm{mg}$ \\
\hline
\end{tabular}

$6.8 \mathrm{mg} /$ day (only $57 \%$ of the RDI for vegetarian women [Box 2]) compared with $8.4 \mathrm{mg} /$ day in omnivorous women. ${ }^{30}$ Vegetarian men had a similar mean dietary zinc intake to omnivorous men; the intake of $11.1 \mathrm{mg} /$ day for male lacto-ovo-vegetarians represented only $53 \%$ of the RDI of zinc for vegetarian men (Box 2). ${ }^{30}$ Despite lower zinc intakes among vegetarians, mean serum zinc levels were similar for female omnivores and vegetarians, and higher in vegetarian men than omnivore men, and vegetarians did not have a significantly greater risk of low zinc status than omnivores. ${ }^{30}$ Other studies have shown that mean serum zinc concentrations for vegetarian subjects were within the normal range. ${ }^{29}$

Zinc balance can be maintained in vegetarians with the inclusion of whole grains and legumes. An 8-week controlled lacto-ovo-vegetarian and non-vegetarian crossover design study showed that although vegetarian diets supplied $14 \%$ less zinc and vegetarian women absorbed $21 \%$ less zinc than the non-vegetarian group, zinc balance was maintained in vegetarian women because less zinc was excreted. ${ }^{31}$ Further, when vegetarians had a similar intake of zinc to omnivores and they consumed the same amount of phytic acid, the absorption of zinc was ultimately dependent on the concentration of zinc in the food. ${ }^{32}$ Modest supplementation of zinc or zinc-fortified plant-derived food products may represent an efficient way of providing further zinc through non-animal-based sources.

Cross-sectional plasma zinc measurements have not usually differed between vegetarians and nonvegetarians. ${ }^{23}$ Because of the body's capacity to respond to fluctuations in dietary zinc intake, plasma and serum zinc levels only significantly drop (or dip) with severe dietary restriction. ${ }^{33}$ Sensitive indices for assessing zinc status are unknown at present and require further research. ${ }^{1}$ Research on metallothionein and zinc transporters is proving promising. ${ }^{2}$

\section{Higher dietary requirements for vegetarians}

The amounts of zinc required for vegetarians and the general population are based on the amount of absorbed zinc necessary to match total daily excretion of endogenous zinc. ${ }^{3}$ Yet the requirement for vegetarians has been set at 1.5 times the zinc requirement of the general population, apparently because of the higher content of phytate in a vegetarian diet, and especially to allow for diets with a phytate : zinc molar ratio $>15$. 3,8,23,14 This does not appear to take into account the adaptative response of reducing losses and increasing absorption efficiencies mentioned earlier.

Of note, the World Health Organization recommends only $14 \mathrm{mg} /$ day of zinc for vegan men (considered to be on a low bioavailability diet), and $7 \mathrm{mg} /$ day for vegetarians and omnivores, ${ }^{1,23}$ which is significantly lower than the Australian recommendation for vegetarian men, of $21 \mathrm{mg} /$ day, to meet $150 \%$ of RDI. (Box 3). The current Australian RDI for men aged 19-70 years who are not vegetarian or vegan is $14 \mathrm{mg} /$ day.

Box 4 shows sources of zinc from plant-derived foods, dairy and eggs in common serve sizes. Food items that are likely to be high in phytate, and not subjected to 
processes that would reduce phytate (heating, leavening, etc), are noted.

A sample meal plan appropriate for lacto-ovovegetarian men, who have the highest zinc requirements of either sex, is shown in Box 5. The sample meal plan also meets the requirements for other key nutrients (except vitamin $\mathrm{D}$ and long-chain omega-3 fatty acids). ${ }^{3}$ Another article in this supplement provides more details on meeting nutrient reference values on a vegetarian diet, as well as other sample meal plans (see page 33).

\section{Conclusion}

Well planned vegetarian diets can provide adequate zinc for all age groups, and vegetarians appear to be at no greater risk of zinc deficiency than non-vegetarians. Important sources of zinc for vegetarians include wholegrains, legumes and soy products, nuts, seeds, as well as fortified cereals and dairy. Vegetarians in Western societies have access to a wide variety of zinc-rich plantderived foods, and methods of food preparation can aid zinc absorption. Concerns regarding the inhibitory effects of phytate on zinc absorption are minimised by modern food processing and cooking methods. RDIs for zinc are formulated on the basis of the results from single meal studies, which do not take into consideration the body's long-term compensatory mechanisms. This homeostatic mechanism adapts to a lower zinc intake by absorbing more zinc and excreting less. Further research is needed to better understand zinc metabolism and requirements in vegetarians.

Acknowledgements: We acknowledge the work of Simon Barden, who is employed by Sanitarium Health and Wellbeing, and Nicole Brown (student dietitian at the time of her contribution), who assisted with a scientific literature review.

Competing interests: Angela Saunders is employed by Sanitarium Health and Wellbeing, sponsor of this supplement.

Provenance: Commissioned by supplement editors; externally peer reviewed.

1 World Health Organization and Food and Agriculture Organization of the United Nations. Vitamin and mineral requirements in human nutrition: report of a joint FAO/WHO expert consultation, Bangkok, Thailand, 21-30 September 1998. 2nd ed. Geneva: FAO/WHO, 2004: 230-245.

2 King JC. Zinc: an essential but elusive nutrient. Am J Clin Nutr 2011; 94 : 679S-684S.

3 National Health and Medical Research Council and New Zealand Ministry of Health. Nutrient reference values for Australia and New Zealand including recommended dietary intakes. Canberra: NHMRC, 2006. http://www.nhmrc.gov.au/guidelines/publications/n35-n36-n37 (accessed Apr 2012).

4 Mahan LK, Escott-Stump S. Krause's food, nutrition, and diet therapy. llth ed. Philadelphia, PA: Saunders Elsevier, 2004

5 Food Standards Australia New Zealand. NUTTAB 2010 online searchable database. http://www.foodstandards.gov.au/consumer information/nuttab2010/nuttab2010onlinesearchabledatabase/ onlineversion.cfm (accessed Jun 2011).

6 Food Standards Australia New Zealand. AUSNUT (Australian Food and Nutrient Database) 2007. AUSNUT 2007 Microsoft Excel files. Nutrient file. http://www.foodstandards.gov.au/consumerinformation/ ausnut2007/ausnut2007microsofte4060.cfm (accessed Jun 2011).

7 Geissler C, Powers H. Human nutrition. 1lth ed. Edinburgh; New York: Elsevier/Churchill Livingstone, 2005.

8 Gibson RS. Zinc nutrition in developing countries. Nutr Res Rev 1994; 7: 151-173.

9 Adams CL, Hambidge M, Raboy V, et al. Zinc absorption from a lowphytic acid maize. Am J Clin Nutr 2002; 76: 556-559.

10 Türk M, Carlsson NG, Sandberg AS. Reduction in the levels of phytate during wholemeal bread making; effect of yeast and wheat phytases. J Cereal Sci 1996; 23: 257-264. doi: 10.1006/jcrs.1996.0026.

11 Samman S. Zinc. Nutrition \& Dietetics 2007; 64 Suppl s4: S131-S134. doi: 10.11l1/j.1747-0080.2007.00200.x.
12 Lönnerdal B. Dietary factors influencing zinc absorption. J Nutr 2000; 130 (5 Suppl): 1378S-1383S

13 Hunt JR, Beiseigel JM, Johnson LK. Adaptation in human zinc absorption as influenced by dietary zinc and bioavailability. Am J Clin Nutr 2008; 87: 1336-1345.

14 Chiplonkar SA, Agte VV. Predicting bioavailable zinc from lower phytate forms, folic acid and their interactions with zinc in vegetarian meals. J Am Coll Nutr 2006; 25: 26-33.

15 Sandström B, Almgren A, Kivistö B, Cederblad A. Zinc absorption in humans from meals based on rye, barley, oatmeal, triticale and whole wheat. J Nutr 1987; 117: 1898-1902.

16 Sandström B, Arvidsson B, Cederblad A, Björn-Rasmussen E Zinc absorption from composite meals. I. The significance of wheat extraction rate, zinc, calcium, and protein content in meals based on bread. Am J Clin Nutr 1980; 33: 739-745.

17 Mangels R, Messina V, Messina M. The dietitian's guide to vegetarian diets: issues and applications. 3rd ed. Sudbury, Mass: Jones \& Bartlett Learning, 2011.

18 Food and Nutrition Board and Institute of Medicine. Dietary reference intakes for vitamin A, vitamin K, arsenic, boron, chromium, copper, iodine, iron, manganese, molybdenum, nickel, silicon, vanadium, and zinc. Washington, DC: National Academy Press, 2001. http:// www.nap.edu/openbook.php?record id=10026\&page=Rl (accessed Apr 2012).

19 National Research Council. Dietary reference intakes: the essential guide to nutrient requirements. Washington, DC: National Academies Press, 2006. http://www.nap.edu/catalog.php?record_id=11537 (accessed May 2012).

20 Krebs NF. Overview of zinc absorption and excretion in the human gastrointestinal tract. J Nutr 2000; 130 (5 Suppl): 1374S-1377S.

21 Maret $\mathrm{W}$, Sandstead $\mathrm{HH}$. Zinc requirements and the risks and benefits of zinc supplementation. J Trace Elem Med Biol 2006; 20: 3-18.

22 Krebs NF, Hambidge KM. Zinc requirements and zinc intakes of breastfed infants. Am J Clin Nutr 1986; 43: 288-292.

23 Hunt JR. Bioavailability of iron, zinc, and other trace minerals from vegetarian diets. Am J Clin Nutr 2003; 78 (3 Suppl): 633S-639S.

24 Srikumar TS, Johansson GK, Ockerman PA, et al. Trace element status in healthy subjects switching from a mixed to a lactovegetarian diet for 12 mo. Am J Clin Nutr 1992; 55: 885-890.

25 Brown KH, Rivera JA, Bhutta Z, et al. International Zinc Nutrition Consultative Group (IZiNCG) technical document \#l. Assessment of the risk of zinc deficiency in populations and options for its control. Food Nutr Bull 2004; 25 (1 Suppl 2): S99-S203.

26 Shankar AH, Prasad AS. Zinc and immune function: the biological basis of altered resistance to infection. Am J Clin Nutr 1998; 68 (2 Suppl): 447S-463S.

27 Black MM. Zinc deficiency and child development. Am J Clin Nutr 1998; 68 (2 Suppl): 464S-469S

28 Baghurst KI, Dreosti IE, Syrette JA, et al. Zinc and magnesium status of Australian adults. Nutr Res 1991; 11: 23-32. doi: 10.1016/S02715317(05)80147-2.

29 Anderson BM, Gibson RS, Sabry JH. The iron and zinc status of longterm vegetarian women. Am J Clin Nutr 1981; 34: 1042-1048.

30 Ball MJ, Ackland ML. Zinc intake and status in Australian vegetarians. Br J Nutr 2000; 83: 27-33.

31 Hunt JR, Matthys LA, Johnson LK. Zinc absorption, mineral balance, and blood lipids in women consuming controlled lactoovovegetarian and omnivorous diets for 8 wk. Am J Clin Nutr 1998; 67: 421-430.

32 Kristensen MB, Hels O, Morberg CM, et al. Total zinc absorption in young women, but not fractional zinc absorption, differs between vegetarian and meat-based diets with equal phytic acid content Br J Nutr 2006; 95: 963-967.

33 King JC, Shames DM, Woodhouse LR. Zinc homeostasis in humans. J Nutr 2000; 130 (5 Suppl): 1360S-1366S.

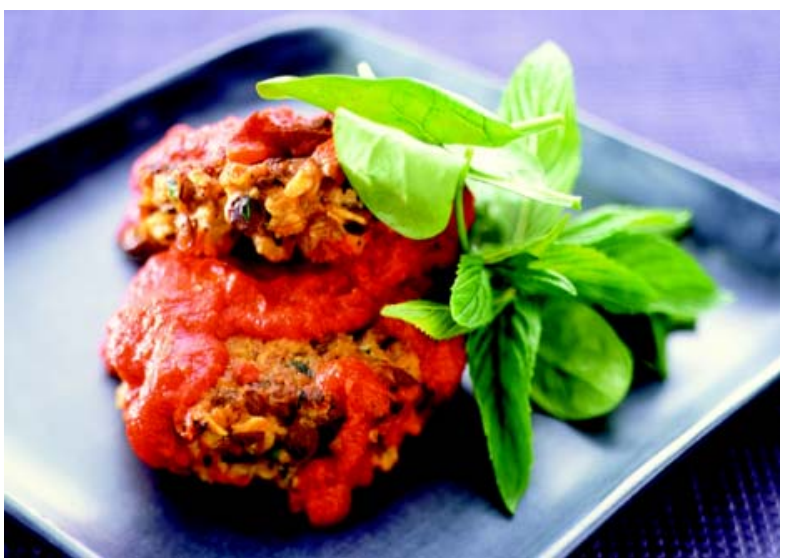


